\title{
Editorial Captive to a political elite
}

7 HIS edition of Pacific Journalism Review is themed on the Media and Democracy in the South Pacific symposium held in Suva in September 2012. Hosted by the University of the South Pacific, the conference has provided most of the core papers for this issue, marking close to two decades of an independent research role in the region by this journal. The 2012 symposium followed two previous conferences held at AUT University in Auckland and USP in Suva in December 2010, covering topics ranging from investigative journalism and technology, peace journalism, democracy, social cohesion and various related themes.

The discourse, and the papers that the conferences spawned, gave a boost to media research and practice in the Pacific, particularly Fiji, under military rule and strict media censorship since 2006. Fiji is a tough, but not wholly insurmountable, problem. Even if the Fiji media are shackled, the conferences of 2010 and 2012 provided opportunity and space to engage in some open dialogue, including criticism of the regime authorities. The proceedings were not confined to the Suva conference venue, or within Fiji's borders - this is the digital age after all.

Questioning and criticising governments is a core role of the media. However, the media do not always show the same robustness when it comes to being reflective about their own conduct. A common theme across some of the papers in this edition is that introspection is necessary for the Pacific media's long-term health and survival, especially in an autocratic environment. This was the unfortunate lesson for Sydney-based News Limited, owner of The Fiji Times, which was forced to sell the title to a local buyer, the Motibhai Group in September 2010.

The symposium showed the need for, and benefits of, pooling knowledge and scarce resources for the benefit of a widely-scattered, remote and impoverished part of the world. It was the culmination of the work of two universities, AUT (Pacific Media Centre) and USP - two different faculties, Arts and Law (FAL) and Business and Economics (FBE) - the United Nations Development Programme (UNDP) in Suva and the Fiji media industry. It brought together working journalists, journalism students, NGOs and academics. Keynote speakers included pioneering independent Tongan 
publisher and broadcaster Kalafi Moala, PMC director Professor David Robie of New Zealand and the University of Queensland's Dr Levi Obijiofor, a Nigerian media authority on coups and military regimes. Papers were published in a special edition of The Journal of Pacific Studies. The conference prompted a lively debate about Western media models and freedom of expression in the Pacific. The 2012 symposium was an important follow-up event needed to keep the momentum alive. It enabled a robust and much-needed discussion about media and democracy in Fiji with a form of democracy due to return next year.

In terms of media models, Pacific media commentators aside, even those from Western countries caution against indiscriminate acceptance of the dominant paradigm. Canadian communications professor Robert A. Hackett warns of 'significant democratic shortcomings' in media's watchdog, public sphere, community-building and communication equity roles. He advocates 'critical selectivity' over 'wholesale adoption' of Western media models in the South Pacific to avoid some 'entrenched shortcomings' of the prototype. Hackett, co-editor of the insightful Sydney University book re-examining global communication philosophies, rights and standards, Expanding Peace Journalism: Comparative and Critical Approaches (2011), gave the keynote address at the USP symposium.

A call for papers for the conference referenced the PMC's inaugural Media Freedom in the Pacific: A Status Report (2011) and cited the following factors impinging upon media freedom models in Pacific nations: 1) cultural issues involving the reconciliation of media ideals and values with entrenched tribal or communal authority; 2) small communities with many conflicts of interest; 3) problems of educating populations about dealing with the media; and 4) a lack of access to media experienced by many communities.

Entrenched shortcomings highlighted by Hackett may have taken root already, as shown by Shazia Usman's study on the Fiji print media's coverage of female candidates in the country's 2006 elections in this edition of PJR. Reflecting international trends, the Fiji daily newspapers lavished attention on male candidates while cold-shouldering female candidates. The Fiji Times quoted female candidates 20 times and male candidates 218 times, while the Fiji Sun quoted females 29 times, and males 292 times.

The lopsided coverage can be attributed to the disparity between the number of male and female candidates - 308 to 30 respectively. Still, it needs to 
be questioned whether coverage should purely be a numbers game. As Usman says, women face various cultural and traditional barriers that prevent them from running for Parliament - as a previous themed edition of PJR explored in 2006 (Bedggood \& Oosterman). This means that female election candidates are unlikely to increase in the foreseeable future anywhere in the Pacific. Given women's disadvantaged position, should media go out and consciously promote deserving women candidates, or should it maintain 'impartiality', and continue to be part of a system that is stacked against female election candidates? Opinions on this issue are likely to differ, but it is worth noting that women, who make up half of Fiji's population, have only managed to secure 12 percent of parliamentary seats since independence in 1970.

Usman's findings have parallels with Shailendra Singh's article on conflict reporting in Fiji. The article discusses the preliminary findings of a national media survey conducted in 2012 and content analysis of coverage of Fiji's 2006 elections. The findings suggest a relatively young, inexperienced and untrained journalist cohort captive to a political elite that serves as its prime news source. This apparently involves the same male politicians who (according to Usman's study) receive the lion's share of media coverage, crowding out female candidates. In terms of a solution, Singh calls for educating journalists and 'incentivising' journalism. This makes sense: a well-trained and seasoned journalist cohort resistant to rhetoric and able to provide analytical coverage could serve Fiji well.

Fiji could also take hints from David Robie's revised and updated article about news values and journalism strategies in the Pacific, first developed in through a 'Four Worlds' news values prism in the global South (see 2001, p. 13), advocating greater media visibly for Indigenous, ethnic and other minorities marginalised in the 'monocultural Western news model'. He argues that there are distinct approaches to Pacific journalism that, while embracing core notions of the Fourth Estate, also embrace cultural and ethnicity influences. This creates tensions when marginalised groups are shut out of the media. Four Worlds news values parallel Usman's concerns about media marginalisation of women and Singh's work on conflict reporting by providing marginalised, suppressed, and exploited groups with an outlet to vent their grievances openly rather than resort to drastic action, as in the 10-year Bougainville civil war.

Suppression in Fiji is the topic of Mosmi Bhim's article. The military government is preparing the country for elections in September 2014 under a 
controversial new constitution. Bhim writes of media self-censorship, government warnings of a harsh crackdown on 'trouble-makers', and government promises of free, fair, and transparent elections - all in the same breath. With the objective of maintaining the peace, the media can no longer report inflammatory political speeches. But is this a recipe for order? Or will it lead to bottled-up emotions taking more extreme forms?

Like Bhim, American television professor Robert A. Hooper, who has been training Pacific (and other global South) journalists frequently for the past 20 years, paints a grim picture of Fiji. In his latest trip, Hooper encountered a domestic media gagged by lawsuits, a pervasive climate of self-censorship and, for good measure, highly paid US 'spin doctors'. For Hooper, the Fiji crisis reflects the decline of Western interest and influence in the Pacific, with China and even Russia only too eager to fill the void. He provides case studies of Fiji 'censorship in action' as personally experienced with his young student journalist and television industry protégés.

In New Caledonia, Marie M'Bala-Ndi also has some serious questions about public interest journalism and democratic empowerment. In her article, she interrogates the role of the media and argues that it will play a decisive role in the development of the French-ruled Pacific territory, which faces a referendum over independence between 2014 and 2019. She regards the media as 'needing all the tools available to make well-informed decisions regarding the future'.

Toby Ley of the Vanuatu-based Pacific Institute of Public Policy has interviewed a range of journalists in the region and studied digital community media options, and concludes with a challenge: 'The media in the Pacific appear to be faced with a few main options-ignore media freedom issues; write articles overseas about how unfair things are; write the stories they want to at risk of persecution; or attempt to have a positive influence within the imperfect system in which they find themselves.'

In Dunedin, Courtney Wilson and Heather Devere of Otago University's National Centre for Peace and Conflict Studies examine the role of Radio New Zealand's Morning Report programme in relation to conflict reporting and the framing of issues in the region. Reports of their initial content analysis findings at the Fiji symposium prompted a controversy in New Zealand media circles.

Rounding off the edition democracy theme, Thomas Petersson of Stockholm University writes about the 'invisibility' of West Papuans in the Swedish 
press based on a content analysis of 27 newspapers and periodicals. Within the realm of Swedish journalism, he argues that West Papua remains 'an almost impregnable antipole to the civilised West'. But then he could be describing much of the world's press, including that of New Zealand, which has an extraordinary media 'blind spot' about one of its relatively near neighbours.

In the last two issues, we introduced our new Frontline section, which is edited by Wendy Bacon, a professor with the Australian Centre for Independent Journalism at the University of Technology, Sydney (UTS). Frontline aims to develop links between theory and practice in journalism research by publishing exegeses in which practice-based researchers interrogate their own journalism production. In these exegeses, journalists tease out the methodologies and conceptual frameworks which explain how they produce fresh knowledge (Bacon, 2012). In this edition, Bridget Fitzgerald discusses how she approached three substantial features on climate change in local Australian contexts. The Pacific Journalism Review editorial team hopes that this and future exegeses will contribute to building and strengthening a culture of practice-based journalism research inside the academy.

Two articles about the 2008 Beijing Olympic Games examine coverage from varying perspectives. First, Jing Xin of Wuhan University and Donald Matheson of the University of Canterbury reflect on the rapid growth of Chinese web-based news practices and the distinctive dynamics involved. The authors argue that scholarship needs to be less reliant on methodologies developed to analyse Anglo-American websites for Chinese-based research. In the other article, Dianne Jones of the University of Southern Queensland examines the four-fold gender gap favouring male athletes demonstrated by a content analysis of four television networks-ABC, BBC, CBC and TVNZ.

Allan Lee and Greg Treadwell at AUT University explore the conflicted attitudes over writing style for online news media in Australia and New Zealand. Unlike writing for newspapers where conformity to a house style supporting clarity and ease of reading has been long entrenched, the authors find that online style is still a mixed bag and many news organisations need to grapple with this issue.

Concluding this edition is a commentary by Lyn Barnes, also of AUT, who asks whether young journalists are being prepared well enough for reporting traumatic incidents, especially when faced with the pressure of tough economic times and the fast-paced changes in journalism. Since she began 
raising this issue and went on a fellowship to the Dart Centre for Journalism and Trauma at Columbia University in June 2012, she has been working closely with Fairfax Media (NZ) to improve industry strategies over trauma reporting - a positive development from this research.

\section{Shailendra Singh and Professor David Robie}

University of Queensland/University of the South Pacific

Pacific Media Centre, AUT University

www.pjreview.info

\section{References}

Bacon, W. (2012). An innovative direction in academic journalism. Pacific Journalism Review, 18(2), 153-165.

Bedggood, J. and Osterman, A. (Eds) (2006). Contemporary gender issues [Themed edition]. Pacific Journalism Review, 12(1), 1-195.

Perrottet, A., and Robie, D. (2012). Pacific media freedom 2011: A status report. Pacific Journalism Monographs, 41pp. No. 1.

Robie, D. (Ed.). (2001). The Pacific journalist: A practical guide. Suva: University of the South Pacific Book Centre. 